\title{
The Rhetoric of Sexual Difference in French Reproductive Politics
}

\author{
Jill Drouillard | ORCID: 0000-0001-6606-6019 \\ Department of Languages, Literature, \& Philosophy, \\ Mississippi University for Women, Columbus, USA \\ jmdrouillard@muw.edu
}

\begin{abstract}
What kind of rhetoric frames French reproductive policy debate? Who does such policies exclude? Through an examination of the "American import" of gender studies, along with an analysis of France's Catholic heritage and secular politics, I argue that an unwavering belief in sexual difference as the foundation of French society defines the productive reproductive citizen. Sylviane Agacinski is perhaps the most vocal public philosopher who has framed the terms of reproductive policy debate in France, building an oppositional platform to reproductive technology around anthropological assertions of sexual difference. This paper engages with Agacinski to examine rhetorical claims of sexual difference and how such claims delayed passage of France's revised bioethics legislation that extends access of assisted reproductive technology (ART) to "all women." Though the "PMA pour toutes" [ART for all women] legislation was eventually passed, such rhetoric motivated the explicit exclusion of all trans person from its extension, thus hardly permitting ART to all women.
\end{abstract}

\section{Keywords}

French reproductive politics - assisted reproductive technology - Agacinski - sexual difference - trans studies - Butler 
In June 2021, after two years of heated debates, the French National Assembly adopted a measure of its revised bioethics legislation, touted as "PMA pour toutes" [ART for all women], thus extending assisted reproductive technology to single women and lesbian couples. The decree was made official in September 2021. ${ }^{1}$ When I initially wrote this article between March and April 2021, France was reckoning with the aftermath of a February 2021 decision that rejected the revised legislation's most emblematic measure, the aforementioned extension that would allow all women access to ART. ${ }^{2}$ Leaving the problem of how single women and lesbian couples account for "all" women momentarily aside, a point to which I will later return, this paper examines the rhetoric of reproduction that made the rejection in February 2021 possible. I also demonstrate that despite the eventual adoption of an ART extension, the ideology of sexual difference on which French reproductive policy rests is responsible for the explicit exclusion of trans persons from the extension.

First, I would like to explore the political climate that made February's rejection possible. Around the same time of this new bioethics bill adoption, an affair of "islamo-gauchisme" spread across France as "moral academic police" questioned whether intellectual traditions of postcolonial studies, critical race theory, and gender studies posed a danger to French society. ${ }^{3}$ The term "islamo-gauchisme" represents a radical leftism, a politics so extreme, we are told, that it risks supporting Islamic mores, values viewed as incompatible with French secular culture. For example, the aforementioned disciplines, such as gender studies, may promote dangerous rhetoric that lends support to unpatriotic practices such as the "veiling" of women, a practice forbidden in French public schools. The overlapping of these events is no coincidence, as fears surrounding the "American import" of gender studies are intricately linked to the failure of France's revised bioethics legislation. This is not the first time that

1 Here is a link to the official government site that announces the decree of its ART extension. The announcement is titled, "La PMA pour toutes les femmes est authorisée" [ART for all women is authorized]. Note how the text asserts that all women have access to ART, making the precision that "all women" includes heterosexual, homosexual, and single women. Trans women are ignored. Last accessed on Oct. 23. 2021. https://www.service-public.fr/ particuliers/actualites/A152O3.

2 When I refer to having access to reproductive technology in France, I am referring to having access to sperm banks and in vitro fertilization (IVF). Surrogacy is illegal in France.

3 See, for example, Eugénie Bastié, « Théorie du genre, décolonialisme, racialisme ... Ces nouveaux dogmes qui veulent s'imposer en France», Le Figaro, 25 février 2021. Last accessed on Apr. 20, 2021, https://www.lefigaro.fr/actualite-france/theorie-du-genre-decolonialisme -racialisme-ces-nouveaux-dogmes-qui-veulent-s-imposer-en-france-20210225. 
gender studies, known as "la théorie du genre" in France, was cited as a menace and instrumentalized to protest policy change.

In 2013, the manif pour tous, ${ }^{4}$ a movement against the legalization of "samesex" marriage, surrogacy, and extending assisted reproductive technology to single women and lesbian couples, critiqued a program called "l'ABCD de l'égalité," an elementary school pedagogical program initiated by the ministre des Droits de femmes, Najat Vallaud-Belkacem, to combat sexism and to fight against gender stereotypes. This educational initiative was criticized as promoting "l'indifférentiation sexuelle" [sexual indifferentiation]..$^{5}$ The opposition argues that gender studies questions the very foundation of sexual difference on which the fabric of French society relies.

Judith Butler is partly to blame as her seminal text, Gender Trouble, translated into French in 2005 as Trouble dans le genre, has gained a considerable amount of attention within the last decade. Sylviane Agacinski is in direct dialogue with Butler in her 2012 text Femmes entre sexe et genre [Women between sex and gender]. I will return to a discussion of this text and examine how Agacinski sets herself in opposition to Butler by reclaiming the "natural reality" of sexual difference and elevating it to an ontological status, but first, I'd like to briefly sketch out some key ideas found in Gender Trouble. Here, Butler questions ontological constructions of identity, particularly when it comes to defining the category "woman." She is concerned with how representations of identity participate in exclusionary politics by failing to recognize the lives of those that don't fit the unequivocal criteria for membership in a given category. When we speak of "women," who are we leaving out of the conversation? Butler interrogates simplified divisions of sexual difference based on biological destiny and asks, what is "sex" anyway? Is it natural, anatomical, chromosomal, or hormonal, and how is a feminist critique to assess the scientific discourses which purport to establish such "facts" for us? If the immutable character of sex is questioned, and Butler gives convincing arguments for it being so, she states, "perhaps this construct called 'sex' is as culturally constructed as gender; indeed, perhaps it was always already gender, with the consequence that

4 "Manif pour tous" is short for "manifestation pour tous" [demonstration for all]. Manif pour tous is a play on words of "marriage pour tous" [marriage for all], the name of the movement and subsequent legislation that legalized marriage for both heterosexual and homosexual couples.

5 Philippe Euzen, "LABCD de l'égalité', au cœur de la polémique sur la 'théorie du genre," Le Monde, 31 janvier 2014. Last accessed on Oct. 23, 2021. https://www.lemonde.fr/politique/ article/2014/o1/31/qu-est-ce-que-l-abcd-de-l-egalite_4358081_823448.html.

6 Judith Butler, Gender Trouble (New York \& London: Routledge, 199o). 
the distinction between sex and gender turns out to be no distinction at all."7 Thus, for Butler, gender is not the cultural norms ascribed on a naturally sexed body; the very categories of sex, "male" and "female," are the result of a discursive (cultural) process that make them appear natural. Sex is not to nature as gender is to culture, but rather, both are defined according to the knowledge practices of a particular historical period.

Butler's analysis is Foucauldian in that she highlights the discursive production of sex and how regimes of power create the discourse through which categories of sex become created. Foucault was interested in how techniques of power such as the rhetoric of "population" and scientific/psychiatric classifications regulated human sexuality. ${ }^{8}$ Heterosexual unions are seen as necessary for populating productive reproductive citizens, so homosexuality must be framed as a perversity. Biological sex, too, must be controlled in this way to ensure that heterosexual "men" and "women" populate productive reproductive citizens. And yet, access to reproductive technology demonstrates that we do not require the union of heterosexual men and women to populate such constituents. We do not require a familial structure that necessarily includes both patriarch (male) and matriarch (female). This is what is at stake in extending access to reproductive technology to "all" women in France: the rhetoric of population control can no longer maintain natural categories built on claims of sexual difference, a difference that has largely been justified based on the issue of fecundity.

Sexual difference in and of itself does not guarantee a reproductive outcome; this much is acknowledged in allowing heterosexual couples access to reproductive technology. In policy legislation regarding its extension to "all women," it is not the technology in and of itself that is problematic, thus why the February rejection? And, why the express exclusion of trans persons from the eventual adoption of such an extension?

Since France legalized "same-sex" marriage in 2013, debates abound asking whether the right to marry necessitates the right to establish filiation through ART. I put "same-sex" marriage in scare quotes to highlight a problematic that Maggie Nelson underlines in her book The Argonauts, "I don't know many - if

7 Ibid., 10-11.

8 See Michel Foucault, The History of Sexuality: Volume 1: An Introduction (New York: Vintage Books Random House, 1990). 
any - queers who think of their desire's main feature as being 'same-sex'.' 9 I illuminate this caveat because of the emphasis placed on sexual difference in social and legal regulations of reproduction. Non-heterosexual couples are not capable of producing this defining feature of "difference," an alterity required for reproduction. Agacinski has rejected the claim that homosexual marriage necessitates claims to filiation. She asserts that to accept this claim would be to confuse "sexual difference" with the "difference of sexualities" where the former has always been defined in relation to procreation. For Agacinski, sex is a question of biological generation and sexuality is a matter of desire.

In Femmes entre sexes et genre, she states, "J'aimerais montrer dans ce livre que le sexe ne détermine pas la sexualité, mais que la sexualité n'abolit pas le sexe."10 Agacinski is contesting Monique Wittig's assertion that lesbians are not women, a statement with which Butler agrees insofar as she views sexed categories as being a product of what she calls the "heterosexual matrix."11 For Wittig, what it means to be a "woman" is defined by men; to assert that one is not a "woman" is to resist the way women are ordered within a heterosexual society. A perfect example of "woman" as male construction can be seen in Sigmund Freud's claim that "real women" who assume the "correct sexuality" will turn away from their infantile clitoris and move towards the vagina; the vagina makes the "right woman" because it implies penetration, by men bien entendu, and thus heterosexuality. ${ }^{12}$ Butler follows Gayle Rubin's claim in "The Traffic in Women: Notes on the 'Political Economy' of Sex," undergirding that kinships are not founded on biological lineages but are sociocultural constructions built on the exchange of women's bodies as procreative property. Such exchanges make the heterosexual family appear "natural."

Agacinski strongly critiques these claims made by Rubin, and upheld by Butler, lamenting that their assertions go so far as to claim that "le désir d'enfanter résulte [is the result] de pratiques sociales qui nécessitent [require]

$9 \quad$ Maggie Nelson, The Argonauts, (Minneapolis: Graywolf Press, 2015), 25.

10 Sylviane Agacinski, Femmes entre sexe et genre (Paris: Éditions du Seuil, 2012), 6. [Author's translation: "In this book, I would like to show that sex doesn't determine sexuality, but sexuality doesn't abolish sex."]

11 See Monique Wittig's The Straight Mind (Boston: Beacon Press, 1992). Though Wittig herself was French born, the text was first published in English in 1992 and translated almost a decade later into French in 2001. I wonder if the translation was prolonged due to a perceived lack of positive reception from French society. For a discussion of the "heterosexual matrix," see Judith Butler's Gender Trouble (New York \& London: Routledge, 199o), $45^{-100 .}$

12 See Sigmund Freud, "Female Sexuality," The Standard Edition of the Complete Psychological Works of Sigmund Freud, Volume XXI (1927-1931): The Future of an Illusion, Civilizations and its Discontents, and Other Works (1961), 221-244. 
et produisent [produce] ces désirs pour réaliser leurs fins reproductives [English precisions made by Agacinski]".13 Here, she critiques Butler for espousing a theory that credits all maternal desire to the symbolic order of the father. I would not say that Rubin and Butler chalk up all desire to procreate as stemming from the "law of the father." However, I do think they are critical of how our desires are created and whether a so-called "maternal instinct" is a "natural" part of being a "woman." There is, nevertheless, a tension here in thinking about the link between heterosexuality and fecundity. If the desire to procreate is the product of the symbolic order of the "law of the father," an order that supports the heterosexual matrix, then a question arises as to whether nonheterosexual persons effectively escape this desire. Lee Edelman addresses this in his book No Future: Queer Theory and the Death Drive where he calls upon queer persons to engage in non-reproductive futurism by embracing the death drive and choosing not to have children. ${ }^{14}$ Other scholars have highlighted how a push for queer couples to have families may be the product of heterosexual procreative values, thus participating in what Lisa Duggan has called homonormativity..$^{15}$ Now that couples can marry, regardless of their sexuality, does matrimony then lead to the next act of having children, or is such thinking a product of what Wittig would call "the straight mind"?

Again, Agacinski does not think "same-sex" marriage necessitates claims to filiation. She states, "le mariage n'a pas été institué pour légaliser l'hétérosexualité mais pour régler la filiation."16 That is, as stated in the French civil code, marriage is an institution that regulates kinship, and such kinship relies on the differential nature of fecundity, a difference only achieved through two distinct sexes. Agacinski is thus stating that marriage doesn't authorize heterosexuality and from there codify claims to filiation. Marriage has to do with filiation insofar as it legitimates paternal claims to children. The civil code that Agacinski is referring to was originally established as the Napoleonic code of 1804 that used marriage as a process to establish paternity prior to the invention of DNA testing. Before such verification, there was no way to know for sure who the father was; matrimony was thus a ceremonial process to bestow

13 Sylviane Agacinski, Femmes entre sexe et genre (Paris: Éditions du Seuil, 2012), 15 o. [Author's translation: "The desire to bear children is the result of social practices that require and produce these desires to achieve their reproductive goals."].

14 Lee Edelman, No Future: Queer theory and the death drive (Durham \& London: Duke Univ. Press, 2004).

15 Lisa Duggan, The New Homonormativity: The Sexual Politics of Neoliberalism, (Durham \& London: Duke Univ. Press, 2002).

16 Sylviane Agacinski, Politique des sexes (Paris: Éditions du Seuil, 2001), 13. [Author's translation: "Marriage wasn't instituted to legalize heterosexuality but to regulate filiation."]. 
paternal rights upon a father. The fact that there was no way of knowing paternity readily points to Rubin's point that kinships are not established based on biological lineage but sociocultural constructions. Today, and with DNA tests to prove genetic ties nonetheless, we know that familial constructions do not rely exclusively on biological genealogy. This is made evident by the number of divorces, blended families, and single households. And yet, in the face of this reality, there remains resistance to establishing claims to filiation outside of heterosexual unions.

Like Agacinski, the manif pour tous movement was similarly concerned that "same-sex" marriage would violate previously established grounds of filiation. Proponents of this movement stated,

Le projet de loi 'Mariage pour tous' bouleverse le Code civil en supprimant systématiquement les mots de 'mari' et de 'femme', de 'père' et de 'mère', au profit de termes asexués, indifférenciés (notamment 'parents'). Ce projet entend ainsi supprimer légalement l'altérité sexuelle et remettre en cause le fondement de l'identité humaine: la différence sexuelle et la filiation en résultant. Il ouvre la voie à une nouvelle filiation 'sociale', sans rapport avec la réalité humaine. Il crée le cadre d'un nouvel ordre anthropologique, fondé non plus sur le sexe mais sur le genre, la préférence sexuelle. ${ }^{17}$

The manif pour tous references the same endangered civil code that Agacinski highlights, the Napoleonic Code of 1804 . Again, this code assesses paternity based on matrimony, thus securing familial ties; here, marriage establishes filiation. Yet, with the modernization of the family in the 1970 and the introduction of divorce into the civil code, marriage was no longer seen as the harbinger of kinship. Mother A and Father B could divorce, but such dissolution of the family did not breach lines of filiation, as A and B still held claims to their kin based on genetic ties. Thus, until the legalization of "same sex" marriage,

17 This message appeared on their website in 2013 under the topic "Qui sommes-nous" and has since been revised. https://www.lamanifpourtous.fr/fr/qui-sommes-nous/notre -message. Last accessed in May 2014. [Author's translation: "The project of the 'Marriage for all' law upsets the civil code by systematically deleting the words 'husband' and 'wife' and 'mother' and 'father' in favor of asexual, undifferentiated terms (notably 'parents'). This project thus intends to legally delete sexual alterity and to put into question the foundation of human identity: sexual difference and the filiation that results from it. It opens the path to a new 'social' filiation, without relation to human reality. It creates the framework for a new anthropological order, founded no longer on sex but on gender, sexual preference."] 
biological descendancy had defined the make-up of the family. The problem with this train of thought is that over the past 40 years the family has undergone rapid transformation so much so that we can no longer speak of "family" but "families." As Irène Théry asserts,

La métamorphose de l'institution familiale se traduit d'abord par un premier grand moment de modernisation dans les années 1970, partout en Occident. Pour la France, c'est une impressionnante succession de réformes du droit de la famille : réformes des régimes matrimoniaux (1965), création de l'adoption plénière (1966), passage de la puissance paternelle à l'autorité parentale (1970), égalité des filiations légitime et naturelle (1972), légalisation de l'avortement (1975), divorce par consentement mutuel (1975). ${ }^{18}$

Given such changes to the civil code and corresponding mutations within the familial unit, we cannot define family in terms of a heterosexual married couple with genetically related children. Families may get divorced and blend with other families, they may never get married at all, and single parents, largely mothers, make up $21 \%$ of French households. ${ }^{19}$ The reality of the varied composition of French families appeared to have reached somewhat of a consensus and the road was paved for extending access to reproductive technologies to single women and lesbian couples to account for this shift. French President Emmanuel Macron supported such a revision in bioethics legislation and both the National Assembly and Senate had initially voted in favor of the bill

18 Théry, Irène (dir.). Filiations, Origines, Parentalité : le droit face aux nouvelles valeurs de responsabilité générationnelle, Rapport du groupe de travail Filiation, Origines, Parentalité, Irène Théry présidente, Anne-Marie Leroyer rapporteure, 2014, p. 16. [Author's translation: "The metamorphosis of the familial institution had its first huge modern transformation in the 1970s, everywhere in the West. In France, this takes place as a striking series of reforms in family law: marital property system reforms (1965), creation of full adoption (1966), move from paternal power to parental authority (1970), equal status of children regardless if they were conceived through marriage (1972), legalization of abortion (1975), divorce by mutual consent (1975)."]

19 According to the Institut National d'Études Démographiques (INED), 21\% of children live with a single parent. That number increases as the child grows in age, beginning to steadily rise after the child bypasses 3 years of age. Last accessed on Apr. 17, 2021, https:// www.ined.fr/en/everything_about_population/demographic-facts-sheets/faq/france -single-parent-family/\#: :text=Single\%2Dparent\%2ofamilies\%2oare\%2ofamilies,in\%2o a\%2osingle $\% 2$ Dparent $\% 20$ family. 
touted as "PMA pour toutes" [ART for all women]. ${ }^{20}$ Again, what happened in February? Why was this measure rejected?

France's conservative politics of reproduction can be attributed, in part, to its Catholic heritage, a legacy made obvious if one were to visit on a Sunday and search for an open bakery. The Catholic Church has long opposed any form of technological intervention, including access to sperm banks and IVF for heterosexual couples. In 1987, Donum Vitae was published by the Congregation for the Doctrine of the Faith, a text that explicitly asserts that a child must be born via carnal procreation whereby a man and a woman actualize the fundamental values of love and life. ${ }^{21}$ The valorization of carnal procreation can be seen in protest media opposing both non-heterosexual marriage and children born via ART, for example, signs reading "Génération Bio. Naturellement Riche. Enfant = 1 papa + 1 maman. Respectons la nature humaine," as well as street stencils marking, "Nous voulons des enfants bios." ${ }^{22}$ While the position of the Catholic faith has long been clear, 2019 saw an increase in media coverage regarding religious-based opposition to the proposed bioethics legislation. For example, Le Figaro published an article "PMA: l'église catholique 'inquiète' de la loi bioéthique," and The Conversation asks "Les Français catholiques se reconnaissent-ils dans la marche du 6 octobre?," a march organized by the manif pour tous in opposition to both assisted reproductive technology that would erase fathers, thus ART open to single women and lesbian couples, and surrogacy [contre la $P M A$ sans pères et la GPA $].{ }^{23}$ What is interesting about this latter article is its accompanying image, a picture of the manif pour tous's 2016 protest against la théorie du genre [gender theory], an association that once again blames gender theory for the dissolution of the nuclear family.

20 Macron has long supported the extension of ART to single women and lesbian couples, promising a revised bioethics legislation as part of his presidential campaign. For example, on Feb. 16, 2017, he tweeted, "Le fait que la PMA ne soit pas ouverte aux couples de femmes et aux femmes seules est une discrimination intolérable" [Author's translation: "The fact that ART is not open to lesbian couples and single women is an intolerable discrimination."].

21 The Congregation for the Doctrine of the Faith, Donum Vitae, 1987. Last accessed on April 6, 2021 at https://www.vatican.va/roman_curia/congregations/cfaith/documents/ rc_con_cfaith_doc_19870222_respect-for-human-life_en.html.

22 [Author's translation: "Organic Generation. Naturally Rich (in the same way a food product may be rich in nutrients). Infant $=1$ papa +1 mama. Respect human nature" and "We want organic children."].

23 The title of Le Figaro article may be translated as "ART: The Catholic Church worries about the bioethics law," and The Conversation title asks, "Do French Catholics see themselves in the march/protest of Oct. 6th?". 
Yet, how can Catholic values be responsible for France's rejection of the revised bioethics legislation, when its country is governed by secular politics [laïcité], founded on principles of universalism? According to such principles, particular individuals may not receive "special" treatment. For example, upholding a separation of church and state, France has barred all students from wearing any ostentatious religious symbols in school. Though this may seem "just" on the face of it, that no one is allowed to wear religious symbols based on this universal ideal of "Frenchness," it explicitly targets certain religions (i.e. Muslims who veil) viewed as incompatible with a particular understanding of French culture (one separated completely from religion, but not really, because bakeries are closed on Sundays). ${ }^{24}$ The accent on "ostentatious" makes it so that a Christian student may wear a gold chain with a small cross, but a Muslim veil cannot be removed from view.

The aforementioned article from The Conversation notes that while Catholic voices were initially muted in light of such politics of laïcité, there has been a resurgence of politicians unapologetically "confessing" their Christianity in resistance to the faith's marginalization. For example, Nicolas Sarkozy has valorized the Christian roots of France and "dans son discours au Palais du Latran en 2009, place même le prêtre au-dessus de l'instituteur"; in 2012, François Fillon, who served as prime minister under Sarkozy, revealed, "je suis chrétien" [I am christian].${ }^{25}$ The confessional tone of these declarations is remarkable, for as Foucault notes, such divulgation produces a "speaker's benefit." ${ }^{26}$ Insofar as the Christian voice is seen as politically incompatible with secularism, to speak of one's faith as a politician, especially one of such high ranking, is almost taboo. To speak of that which is supposed to be silenced, gives the speaker the feeling that he has committed a transgression, and so Fillon's avowal of being a Christian is seen as liberating. Did such remarks incite other French citizens to feel that they too could be liberated by assuming France's Christian roots? Were these religious revelations, almost confessional in nature, supposed to reinstate Christian values in a country that only pretended secularism as

24 For an in-depth discussion of French secular politics and how the 2004 government ban of ostentatious religious symbols in public schools targeted wearers of "the veil," see Joan Wallach Scott, The Politics of the Veil (Princeton \& Oxford: Princeton University Press, 2007).

25 "Les Français catholiques se reconnaissent-ils dans la marche du 6 octobre?” The Conversation, October 3, 2019. Last accessed on Apr. 17, 2021, https://theconversation.com/les -francais-catholiques-se-reconnaissent-ils-dans-la-marche-du-6-octobre-124644. [Author's translation: "In his 2009 speech at the Lateran Palace, he places the priest above the teacher."].

26 Michel Foucault, The History of Sexuality: Volume 1: An Introduction (New York: Vintage Books Random House, 1990). 
protection against other faiths, namely Islam? If so, the current affair of "islamo-gauchisme" is even more understandable, and the need to reinforce secular politics of universalism is more important than ever. Such principles that allow no "special cases" extends to not only the donning of religious symbols but to cases that would upset sexual difference and its correlating valorization of carnal procreation, the only form of reproduction acceptable by the Catholic church.

This restriction of no "special" cases regardless of justifiable differences in kind had been used to bar non-heterosexual couples from gaining access to assisted reproductive technology. Prior to the ART extension, a heterosexual couple had recourse to ART if the couple was deemed infertile (after two years of attempted carnal procreation), or if they were trying to avoid passing a genetic defect onto their child. Opponents of the ART extension argued that a single woman or two women do not request ART on the grounds of infertility and thus are demanding to be treated as "special cases," and such cases are in conflict with universalism.

However, perhaps the real rhetoric that drives debates in opposition to extending ART to non-heterosexual couples is not religious or secular in nature but rather is built upon the anthropological claim that the fabric of our social order relies on the heteronormative structure of sexual difference. Like the universal concept of "Frenchness," sexual difference presumes metaphysical ideas of "femaleness" and "maleness" that are as eternal and unchanging as Plato's forms. What remains static and separate from religious or secular ideals, is a sex/gender binary that idealizes the heterosexual couple as the pillar of French society.

Following the logic of Claude Lévi-Strauss, Agacinski asserts the parenting model (mother/father) mirrors our biological foundation (female/male), noting that such a model is not quantitative $1+1$, but qualitative male + female. ${ }^{27}$ Thus, non-heterosexual couples do not possess the right qualia to reproduce. What is noteworthy about Agacinski's formulation is that it mirrors a previously mentioned protest sign, "enfant $=1$ papa +1 maman." Both utterances use the rhetorical strategy of appealing to mathematical equations to demonstrate the objectiveness and universality of their statements. $2+2$ cannot equal anything but 4, and similarly, 1 infant cannot exist without 1 female and 1 male parent; but, if the latter statement was true in and of itself, there would be no margin of error. If an infant could not live without both differently sexed parents, then

27 Sylviane Agacinski, «Deux mères = un père? », Le Monde, 3 février 2013. Last accessed on Apr. 17, 2021, https://www.lemonde.fr/idees/article/2013/o2/o3/deux-meres-un-pere _1826278_3232.html. 
how can we explain single-headed households, or non-heterosexual families with adopted children? "Maman" and "papa" are social terms, as can be seen in the colloquial English saying that a "father" doesn't make a "daddy," meaning DNA alone does not permit access to kinship. If statements such as "enfant = 1 papa + 1 maman" is supposed to point to a biological fact that a meeting of egg and sperm must be joined to create a child, this truth was never under attack; single women and lesbians know they need this differential gamete to procreate, hence their demanding to have access to sperm banks. Agacinski believes that this biological fact regarding the differential nature of fecundity is neglected by gender theory, as this discipline teaches persons they can be whatever sex or gender they want regardless of the reality of "natural" facts.

Agacinski asserts,

En niant, ou en déniant, les fondements biologiques de la distinction de sexe, on compromet toute possibilité de comprendre la construction des formes historiques de la servitude spécifiques des femmes (l'enfantement), qu'elles soient anciennes (avec la famille patriarcale) ou modernes (avec le marché prostitutionnel ou le marché biologique du corps féminin) ... le culturalisme queer et ses épigones français décrètent que la nature n'est rien. $^{28}$

On the one hand, Agacinski may not be completely out of line for criticizing an interpretation of queer theory that views everything as a discursive cultural product. Karen Barad, for example, in "Posthumanist Performativity: Toward an Understanding of How Matter Comes to Matter" begins with the critical statement, "language has been granted too much power." 29 And yet, Barad is able to focus on matter without turning "natural stuff" into fixed categories and without reverting to biological essentialism. Furthermore, Elizabeth Grosz not only discusses the potential of "nature" to be other than what it is, thus critiquing historical viewpoints that relegate it to passive matter, but she also does so

28 Sylviane Agacinski. Femmes entre sexe et genre (Paris: Éditions du Seuil, 2012), 10-14. [Author's translation: "In contradicting, or in denying, the biological foundations of sex distinction, we compromise all possibility of understanding the historical constructions of the oppression of women (childbearing), whether they be ancient (with the patriarchal family) or modern (with prostitution and the biological market of women's bodies) ... queer culture and its French disciples decree that nature is nothing."]

29 Karen Barad, "Posthumanist performativity: Toward an understanding of how matter comes to matter," Signs: Journal of women in society and culture 28, no. 3 (2003), 801-831. 
while recognizing the importance of sexual difference for generation. ${ }^{30}$ There has been a trend in the United States to focus more on what has been deemed "feminist new materialisms," a body of scholarship that studies the dynamism and multiplicity found in nature. I mention this to highlight that it is possible to think about nature, and perhaps sexual difference, without falling into an essentialism that participates in exclusionary reproductive politics.

Agacinski's statement that we cannot understand the historical oppression of women if we deny the biological distinction of the two sexes is reminiscent of the language used by gender critical feminists in the United States (also known as TERFs or trans exclusionary radical feminists). ${ }^{31}$ These feminists believe that women will only be liberated once they understand the historical root of their oppression, a root that is founded in their biological construction as women. Catherine MacKinnon strongly rejects this notion that women must be defined according to their biology to gain liberation, rather accurately declaring, "[m]ale dominant society has defined women as a discrete biological group. If this was going to produce liberation, we'd be free."32

When Agacinski talks about the difference of the sexes and how they are founded based on the biological fact of generation, she claims to be talking about "nature," and so she is able to accuse gender theorists of denying its importance at the expense of culture; however, the claims she makes regarding the necessity of having one mother and one father are cultural ones. Again, granting access to single women and lesbian couples, for example, does not deny biology, as they request access to such organic matter. While the coupling of two distinct gametes is required for generation, one cannot jump, from this fact, to the false claim that two distinct gametes are required for familial construction. A point of Rubin's text is to highlight that women's bodies had been ordered in such a way and had been led to believe that procreative capacity,

$30 \quad$ Elizabeth Grosz, Becoming undone: Darwinian reflections on life, politics, \& art (Durham \& London: Duke Univ. Press, 2011).

31 Gender critical feminists such as Kathleen Stock view the term TERF as a slur, thus rejecting such a label. However, opponents of gender critical feminists contend that if you fail to perceive trans women as "women" based on an essentialist biological notion of what it means to be a woman, a notion that conflates womanhood with the existence of a vagina, you are, by definition, trans exclusionary. The term TERF can be problematic in its focus on radical feminism, for even though many trans exclusionary feminists stem from the radical feminist movement of the second wave (Mary Daly, Germaine Greer, Sheila Jeffreys), not all radical feminists are trans exclusionary. Catherine MacKinnon is a case in point.

32 Cristan Williams, "Sex, Gender, \& Sexuality: An Interview with Catherine A. MacKinnon," The Conversations Project. Last accessed Apr. 17, 2021, http://radfem.transadvocate.com/ sex-gender-and-sexuality-an-interview-with-catharine-a-mackinnon/. 
sexuality, and kinship were necessarily connected. We know from the reality of familial constructions that this is not the case. Agacinski fears that if we deny the duality of sex, "il n'y a plus aucune espèce de raison pour que les parents soient deux et seulement deux. Pourquoi pas trois pères, ou quatre mères? Le modèle binaire du couple n'est pas produit par l'amour ou le plaisir mais par la sexuation, c'est à dire la différentiation génitale."33 Agacinski poses a good question, even though it is derisively asked and is supposed to shock us into a binary way of thinking - why must the parenting model be limited to two? The simple answer is it doesn't need to be, and the fact that Agacinski continues to think that it does further justifies Rubin's point of how women's bodies have been ordered as procreative property to think so. ${ }^{34}$

I like to use this term "ordered" as procreative property in response to another one of Agacinki's claims regarding women's relation to reproductive technology. In her text, Corps en miettes [Body in pieces], Agacinski appeals to Martin Heidegger's philosophy of technology to illustrate how women's bodies are used as resources in the reproductive technology industry. ${ }^{35}$ Heidegger asserts that each historical era approaches being(s) through a particular mode of revealing; our era is characterized by a technological ideology [Gestell] that views everything as an amalgam of resources ready to be calculated, ordered, exploited, and put on reserve for future utility. ${ }^{36} \mathrm{He}$ calls such resources the standing reserve [Bestand]. Agacinski views reproductive technology as a part of this technological thinking that views women's bodies as procreative resources. On the one hand, yes, such technology certainly can exploit women's bodies, and yes, such technology requires the sort of calculative thinking that both Heidegger and Agacinski question. ${ }^{37}$ But, on the other hand, as Heidegger highlights, Gestell is nothing technological in terms of instruments

Sylviane Agacinski. Femmes entre sexe et genre (Paris: Éditions du Seuil, 2012), 15. [Author's translation: "There is no longer any reason that parents be two and only two. Why not three fathers, or four mothers? The binary model of the couple is not produced by love or pleasure but by sexuation, that is to say, genital differentiation."]

34 For a critique of the "natural" binary parenting model see bell hooks, "Revolutionary Parenting," Feminist Theory: From Margin to Center, South End Press and Ed. (2000).

35 Sylviane Agacinski, Corps en Miettes (Paris: Flammarion, 2009).

36 Martin Heidegger, "The Question Concerning Technology," Basic Writings ed. David Krell (San Francisco: Harper Collins, 1993), 311-341.

37 For an account of the exploitative nature of reproductive technology, see Gena Corea, The Mother Machine: Reproductive Technologies from Artificial Insemination to Artificial Wombs (San Francisco: Harper Collins, 1986). For a discussion of how Heidegger's philosophy may be used to illustrate women's bodies as part of the standing reserve, see Dana S. Belu, Heidegger, Reproductive Technology, \& the Motherless Age (Palgrave Macmillan, 2017). 
of technology. We may ban access to ART, but the thought that gave birth to it would still remain. That is, the ideology and desire that created such instruments would not disappear with the prohibition of them. Furthermore, insofar, as technological thinking does not require apparatuses, one could make the argument that any form of ideology, such as "the heterosexual matrix" orders women's bodies as part of the "standing reserve." For example, there is no justifiable reason why parents must be a "couple," let alone one comprised of two distinct sexes. Social mores and legal restrictions order that it be so.

While Agacinski has accused Rubin and Butler for paying too much attention to the symbolic order of the "law of the father," a surprising amount of attention has been bestowed upon fathers and their absence in debates regarding the extension of ART to "all women." Those opposing such extension believe that access to ART would usher in a fatherless society. This fear of paternal neglect is witnessed in protest signs that read, "Liberty, Equality, Paternity," a play on words of the French motto, "Liberty, Equality, Fraternity." Others simply say, "NO to ART without fathers." Still others focus on the perceived emotional damage done to fatherless children who ask, "what is it like to have a daddy?"

Judith Butler briefly addresses this focus on the "father" in her book Frames of War: When Life is Grievable. She is primarily interested in the rhetorical framing of war, including the discourse that makes it easier to wage war and the nationalist language that delineates boundaries between "us" and "them." Such boundaries make some lives grievable, while insinuating that others are not worthy of life. However, in the introduction to her book, she notes that the knowledge-practice of framing may extend to issues regarding reproductive freedom as well. In her chapter "Sexual Politics, Torture, and Secular Time," Butler highlights how the symbolic order that establishes norms of kinship informs France's "progressive" sexual politics. She asserts,

In France, the notion of a 'framework of orientation' - called 'le repère' is understood to be uniquely transmitted by the father ... To the extent that heterosexual marriage maintains its monopoly on reproduction, it does so precisely through privileging the biological father as the representative of national culture. ${ }^{38}$

"Le repère" is the "knowing orientation" by which someone may find their way home, like a landmark that directs you to the right location. In the word "repère" is the French word for father "père". This double meaning of "father"

38 Judith Butler, Frames of War (London \& New York: Verso, 2009), 112. 
and "knowing orientation" and the intricate relation between them has been highlighted in French protest signs that oppose the extension of reproductive technology to "all women," signs that read, "un enfant a besoin d'amour, mais aussi de rePÉRES!" 39 What's particularly fascinating about this sign is that its ideology is driven by the same claim made by Agacinski that love isn't enough; love doesn't create a couple, different genitalia does. And yet, genitalia is not enough either, as we'll see when we turn to the problematic of the slogan "PMA pour toutes".

Conclusion: “PMA pour toutes," But Who's Outside the Frame?

When I began this paper, I momentarily left the problem as to how single women and lesbian couples were supposed to account for all women aside. I would like to address this now, because there is no better way to demonstrate how so-called natural differences are socially regulated to maintain certain illusions as to who is considered the productive reproductive French citizen.

The measure that extends access to ART to single women and lesbian couples claimed a "PMA pour toutes," and yet trans women (and men for that matter) are explicitly ignored in the new legislation. Manon Beury wrote a personal tribune to Libération recounting how the "PMA pour toutes" bill fails to take into consideration the existence of trans women. ${ }^{40}$ Beury explains that she is in a relationship with a trans woman who had previously frozen her sperm; however, the bill forbids her from using her partner's gametes for IVF. To clarify the situation, trans women may choose to freeze their sperm before transition, because surgery or the use of hormones could interfere with their fertility; though, it is important to note that not all trans women decide to undergo surgery or take hormones. The absurdity of the situation is that her partner's sperm is readily available to perform IVF, but under the legislation, she would be required to use an anonymous donor at a sperm bank. Beury could search for a country willing to use her partner's genetic material for IVF, but even then, her partner would not be legally recognized as a biological parent in France, since a birth certificate requires one mother and one father. Beury's partner is a trans woman, and so she would have to be designated the "adoptive mother."

39 [Author's translation: "a child needs love but also 'knowing orientations'/'fathers".]

40 Manon Beury, «En couple avec une femme trans, je suis exclue de la 'PMA pour toutes', »Libération, 4 août 202O. Last accessed Apr. 19, 2021, https://www.liberation.fr/debats/ 2020/08/o4/en-couple-avec-une-femme-trans-je-suis-exclue-de-la-pma-pour-toutes -1795938/. 
Beury's case undergirds the rigidity of a system that must maintain a sharp association between sexual difference and filiation. Beury's partner is allowed to be a woman, but only if she is willing to accept that women do not have sperm. While the legal recognition of trans women may be seen as progress, it is not, if legislation then bars trans persons the necessary access to establishing filiation. Only recently, since 2017, have French citizens been able to change their legal gender recognition without a sterilization requirement. ${ }^{41}$ Though such citizens may no longer be forcibly sterilized, bioethics legislation that does not address the aforementioned concerns, participate in narratives that reinforce the heterosexual couple as the only model of productive reproduction.

In Beury's case, her and her partner, had the differential gametes, but they could not distinguish themselves along the lines of sex/gender; genitalia or the gametes they produce(d) are not enough. The failure of French bioethics to maintain a clear distinction among the sexes based on generation (genitalia) is further highlighted by the fact that trans men are also excluded from the bill. One could easily say, "Well, the bill is called 'ART for all women,' and trans men have fought hard to be recognized as men," but this misses the point that sex, sexuality, and fecundity are not so neatly packaged. Assuming legal gender recognition should not also assume a congruent reproductive sex. In asking to legally be recognized as a man, a trans man must dissociate himself from his uterus, because "man" and "uterus" are already regulated in such a way as to be a contradiction in terms. So, thus, while a trans man may still possess a uterus, he is unable to have access to a sperm bank or IVF; in his case, neither love nor genitalia is enough. Essentially, in agreeing to be trans, he has given up his procreative rights, unless he gets pregnant through carnal procreation, again, the only acceptable method of procreation according to the Catholic church.

I have ended with a discussion of how trans lives upset France's narrative of sexual difference founded on fecundity, because if differential genitalia is all it takes to access claims to filiation, there would be no reason to exclude all trans persons from legislation that would extend access to ART. In conclusion, the rhetoric of French reproductive politics may be informed by its Catholic heritage and valorization of carnal procreation, secular principles founded on universalism, or a resistance to the "American import" of gender studies, but the thread that unites these intersecting conversations circles back to claims of sexual difference as the foundation of French society.

41 Following a 2017 ruling by the European Court of Human Rights that states such sterilization is in violation of human rights. 


\section{Biography}

Jill Drouillard is Assistant Professor of Philosophy at the Mississippi University for Women. She received her PhD in Philosophy from the Université de ParisSorbonne IV. She has research interests in feminist philosophy, reproductive ethics, 19th-2oth century continental philosophy, and social philosophy in the United States and France. She has published in The International Journal of Feminist Approaches to Bioethics, Continental Philosophy Review, The Journal of French and Francophone Philosophy, Implications Philosophiques, and The New Zealand Journal of French Studies. She has forthcoming work on the hermeneutics of sex/gender facticity, and time reckoning during labor. 